\title{
The Effect of Antibiotic Growth Promoters (AGP) on Antibiotic Resistance and the Digestive System of Broiler Chicken in Sleman, Yogyakarta
}

\author{
Tri Untari ${ }^{1}$, Okti Herawati ${ }^{1}$, Marla Anggita ${ }^{1}$, Widya Asmara ${ }^{1}$, Agnesia Endang Tri Hastuti \\ Wahyuni $^{1}$, Michael Haryadi Wibowo ${ }^{1}$ \\ ${ }^{1}$ Department of Microbiology, Faculty of Veterinary Medicine, Universitas Gadjah Mada, \\ Yogyakarta, Indonesia 55281
}

\begin{abstract}
Chicken is a major source of animal protein consumption in Indonesia. The problem facing the poultry industry is the incidence of resistance which increases mortality of the chicken production. One of the causes of resistance case is the use of antibiotics in feed additives. The public understanding about the effects of the use of antibiotic growth promoters (AGP) in chickens in antibiotic resistance and the digestive tract of chicken needs to be done to avoid the impact on economic losses and health problems. This study aims to provide an understanding of the effects of the use of antibiotic growth promoters (AGP) on antibiotic resistance and the digestive tract of broiler chickens. This study was carried out at a broiler chicken farm in Sleman, Yogyakarta. Based on the histopathological result of the digestive tract of chickens that were given antibiotics as AGP, there was no inflammation occurs, but the administration of antibiotics caused antibiotic resistance in various type of antibiotics including tetracycline (90\% resistance), streptomycin (60\% resistance), amoxicillin $(50 \%$ resistance), erythromycin (80\% resistance), and no resistance for gentamycin.
\end{abstract}

\section{Introduction}

Poultry is acknowledged as the main animal protein source in Indonesia, based on the report from [1]. Indonesia produced 3.275 tons of broiler chicken meat and 5.044 tons of chicken eggs, and the consumption of chicken meat reached $5.600 \mathrm{~kg}$ per capita. In the world, over 90 billion tons of chicken meat produced every year [2]. However, the control and surveillance of antibiotics used in poultry farm is still lacking. A large number of antibiotics used in poultry industry are used for human medicine, and so considered to be of high importance.

Antibiotic resistance is one of the problem faced by the poultry industry that caused the increase of morbidity and mortality of poultry during the outbreaks. Resistance can be transferred to other animals or humans through direct contact, food-produced animal products, or indirectly via environmental pathways [3]. The use of antibiotics in feed 
additives has contributed in the occurrence of antibiotic resistance in the poultry farm. After the first introduction of antibiotic growth promoters, the products have been used in farm animals massively. Antibiotic growth promoters was claimed to improve feed conversion, stimulate growth, and reduce the risk of death in livestock $[4,5]$. However, the mechanism of antibiotics as growth promoters are still unknown. Antibiotics are given through food during the growing period of broiler chickens to prevent diseases [6]

Antibiotic growth promoter (AGP) has been banned in poultry industry in various countries [7]. Indonesia is one of the countries that currently prohibits the use of antibiotics as a feed additive, stated in Law No. 18 article 22 paragraph 4. However, until now the use of AGP is still found in chicken farms in Indonesia. There is still limited information available related to prevalence of what kind of antimicrobial drugs that currently resistant to bacteria in the poultry. An understanding of the effects of using antibiotic growth promoters (AGP) in boiler chickens, especially against antibiotic resistance and the digestive tract, needs to be carried out in the community to avoid the impacts on resistance and economic losses. This study aims to provide an understanding of the effects of using antibiotic growth promoters (AGP) on antibiotic resistance and digestive tract of broilers.

\section{Method}

\subsection{Antibiotic resistance test in cloaca swab samples}

Ten cloacal swabs of chickens were collected and cultured on Blood Agar Plate then incubated for 18-24 hours. Isolated colonies were taken from 4-5 colonies that had the same morphology, then planted in $5 \mathrm{ml}$ of tryptic soy broth. The inoculum were incubated for 2-6 hours until it reaches a turbidity equal to $0.5 \mathrm{McF}$ arland standard, containing 2 x $108 \mathrm{CFU} /$ $\mathrm{ml}$. The inoculum were cultured evenly on Mueller Hinton agar (MHA) using a sterile swab. Five antibiotic disks: gentamicin $10 \mu \mathrm{g}$, tetracycline $30 \mu \mathrm{g}$, streptomycin $10 \mu \mathrm{g}$, amoxicillin $25 \mu \mathrm{g}$ and erythromycin $15 \mu \mathrm{g}$, were placed on the surface of MHA then incubated for 18-24 hours. Determination of antibiotic resistance based on the zone of inhibition formed was compared with the standards recommended by the Clinical Standards Laboratory Institute $[8,9]$.

\subsection{Histopathologic examination of the effect of AGP on the digestive tract of chickens}

We examined the morphological structure of digestion tract in broiler chickens that using AGP as additional feed. Ten of broiler's chicken samples were euthanized with standard protocol, then the intestine part: duodenum, jejunum, and ileum were collected and fixated in the $10 \%$ phosphate buffered formalin. The fixated tissues then processed by paraffin method. Tissue slides were stained using Hematoxilin-Eosin (HE) staining [10].

\section{Result and Discussion}

This study has been carried out to examine the antibiotic resistance and the morphology of digestive tract of the chickens that still use antibiotics as growth promoters in Sleman area, Yogyakarta, Indonesia. Based on laboratory tests, we observed that the bacteria from the chicken cloaca swab showed the resistance against tetracycline $30 \mu \mathrm{g}$, streptomycin $10 \mu \mathrm{g}$, amoxicillin $25 \mu \mathrm{g}$ and erythromycin $15 \mu \mathrm{g}$ with different percentages and no resistance observed against gentamicin $10 \mu \mathrm{g}$ (Figure 1). The highest rates of resistance found in samples was against tetracycline $(90 \%)$, followed by erythromycin $(80 \%)$, amoxicillin 
$(60 \%)$, streptomycin (50\%), and gentamicin $(0 \%)$. The result was substantially higher than the study conducted by Braykov et al. [11] that found the antibiotic resistance of E. coli isolates from poultry production against tetracycline, streptomycin,and amoxicillin were $78,12 \% ; 36,39 \%$; and $1,32 \%$ respectively. Eighty percent $(80 \%)$ Escherichia coli and Salmonella isolated from quail birds were found to be resistant to erythromycin [12]. Escherichia coli in poultry showed a higher resistance level of antimicrobials compared to S. Pullorum against amoxicillin and tetracycline (70\%), 50-70\% against gentamicin, and 20 $50 \%$ against enrofloxacin [13].

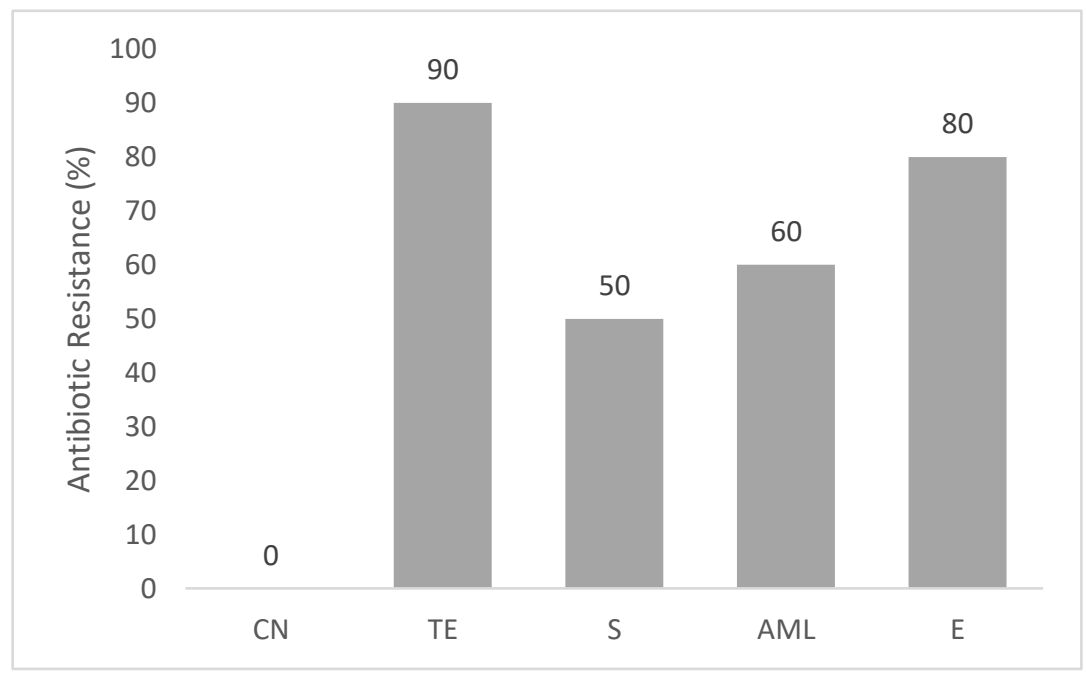

Fig. 1. The prevalence of antibiotic resistance of bacterias from chicken's cloacal swab (CN: gentamicin, TE: tetracycline, S: streptomycine, AML: amoxicilline, E: erythromycin)

In addition, the antimicrobial resistance of bacterial in poultry can occur from the uncontrolled use of antibiotics as AGP, also because precolonized antibiotic-resistant bacteria that already existed in the poultry. The previous study by Chauvin et al. [14] found that $E$. coli isolates collected from French laying hens have higher resistance of beta-lactam antibiotics in young chick. The increased number of resistance against amoxicillinclavulanate, cephalotin, cefotaxime, and gentamicin also found in farm birds, including poultry [15]. The mechanisms of antibiotics resistance might occur in various ways including antibiotic inactivation, membrane permeability reduction, modification of antibiotic targets, and antibiotic transport [16]. Antibiotic inactivation can occur by producing enzymes resulting in decrease of antibiotic function, for example, beta lactamase which destroys the $\beta$-lactam of penicillin, causes the failure of antibiotic adhesion to the bacterial wall peptidoglycan $[16,17]$. Changes in the permeability of bacterial cell membranes can occur due to the genetic mutations, caused antibiotics failing to enter the bacterial cells [17]. Modification of antibiotic targets can lead to resistance because the changes in the structure of the antibiotic target molecules. This caused in the the failure of the antibiotics to meet the targets [18]. Another mechanism of antibiotic resistance is by removing or transporting the antibiotics out of bacterial cells, this occurs in several antibiotics that work in cells including macrolides, tetracyclines and floroquinolones [19].

The histopathological results (Figure 2) showed that there are no inflammation occurred int he intestines from chickens feed with AGP. According to Gulmez et al. [20] the duodenum of chickens with antibioics will show goblet cells, crypt, sub mucosa and mucosa. 
The thick ileum and claw mucosa contribute to increasing body weight (BW) and feed consumption rate (FCR).
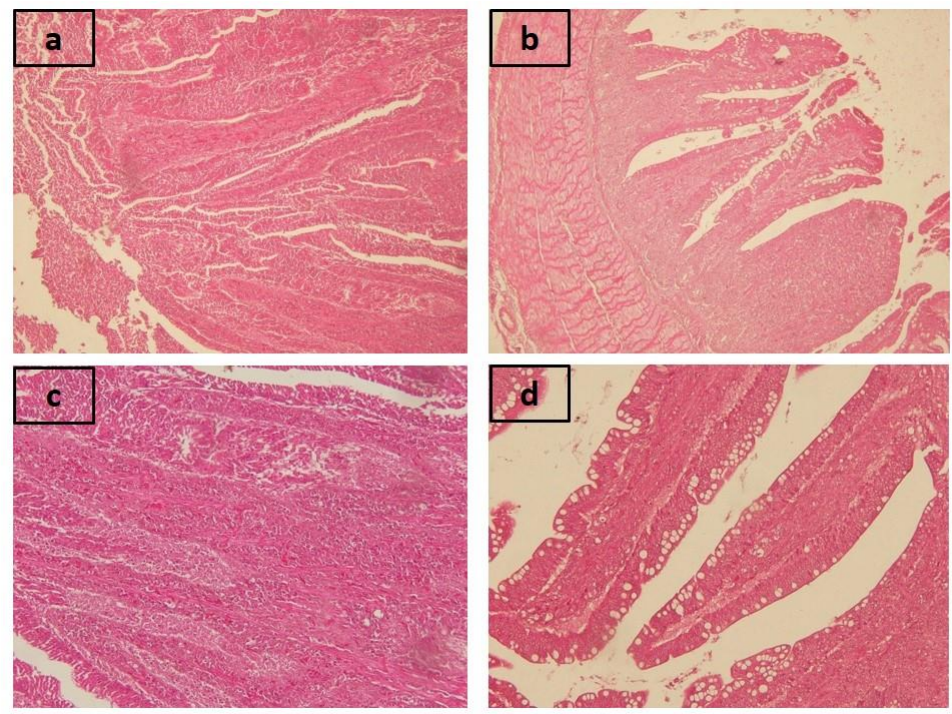

Fig. 2. Histopathological result of broiler's chicken intestine, (a) without AGP, (b) feed with AGP, magnification 4x; (c) inflamatoric cells infiltration in broiler intestine without administration of AGP, (d) no inflamatoric cells infiltration in broiler intestine feed with AGP, magnification 10x,

Hematoxiline-eosin (HE) staining.

Previous study by Rahman et al. [21] stated the high prevalence of antibiotic-resistant E. coli from raw chicken meat from poutry shops. Another study in India found that $78 \%$ of raw chicken meat in poultry shop contaminated with E.coli [22]. The isolates of E.coli and Salmonella $\mathrm{sp}$. from intestine contents were found in prevalence of $65 \%$ and $57,5 \%$ respectively from traditional market in Indonesia [23]. Poultry viscera in some asia country has been the main ingredients of many kinds of foods. The presence of antibiotic-resistant bacteria that can contaminate the viscera in chickens might have the impact on human health, and does not rule out the possibility of the cross-infection of some antibiotic-resistant bacteria if the food does not undergo the hygienic process. Indonesia has a very limited data on antibiotic use in poultry production and the antimicrobial-resistant bacterial strains in poultry. Further studies on the bacterial strains and surveillance on antibiotic use in poultry will be important to reduce the use of AGP in poultry farm.

\section{Conclusion}

The Administration of antibiotics as a growth promoter (AGP) in chicken farms does not cause inflammation in the intestines of chicken but causes antibiotic resistance. The antibiotic resistance of bacterial from cloaca swab of broiler chicken feed with AGP against tetracycline was $90 \%$, followed by erythromycin $80 \%$, amoxicillin $60 \%$, streptomycin $50 \%$, and no resistance against gentamicin.

This study was supported by The Research and Community Service Fund of Faculty of Veterinary Medicine, Gadjah Mada University, with grant number: 1380/UN1/FKH/HK4/2020 


\section{References}

1. Directorate General of Animal Health and Husbandry 2020. Livestock and Animal Health Statistics. Ministry of Agriculture (2020)

2. Food and Agriculture Organization of the United Nations. FAOSTAT: Live Animals Data. Available from: http://www.fao.org/faostat/en (2017)

3. S.J. Dancer. How antibiotics can make us sick: the less obvious adverse effects of antimicrobial chemotherapy. Lancet Infect. Dis. 4 :611-619 (2004)

4. P. Butaye, L. A. Devriese, and F. Haesebrouck. Antimicrobial Growth Promoters Used in Animal Feed: Effects of Less Well Known Antibiotics on Gram-Positive Bacteria. Clinical Microbiology Reviews, 16(2) :175-188. doi:10.1128/cmr.16.2.175188.2003 (2003)

5. N. Ramli, D.M. Suci, S. Sunanto, C. Nugraheni, A. Yulifah, and A. Sofyan. Performan Ayam Broiler yang diberi Ransum Mengandung Potasium Diformate sebagai Pengganti Flavomycin. Agripet. 8(1):1-8 (2005)

6. M.D. Barton and W.S. Hart. Public Health Risks : Antibiotic Resistance Review. AsianAust. J. Anim. Sci. 14(3):414-422 (2001)

7. McEwen S. A. and P. J. Fedorka-Cray. Antimicrobial use and resistance in animals. Clinical Infectious Diseases 34 : 93-106 (2002)

8. A.J. Beleguer, E. Domence, A. Villagra, A. Fenolar and M.A. Ferrus. Antimicrobial resistance of Escherichia coli isolated in newly-hatched chickens and effect of amoxicillin treatment during their growth. Avian. Pathol., 45(4): 501-507 (2016)

9. Clinical and Laboratory Standards Institute. M100-S23: Performance Standards for Antimicrobial Susceptibility Testing; Twenty-Third Informational Supplement (2013)

10. M. Slaoui and L. Fiette. Histopathology procedures: From Tissue Sampling to Histopathological Evaluation. Method in Moleculer Biology. 69 :69 - 82 (2011)

11. N.P. Braykov, J.N.S. Eisenberg, M. Grossman, L. Zhang, K. Vasco, W. Cevallos, D. Muñoz, A. Acevedo, K.A. Moser, C.F. Marrs, B. Foxman, J. Trostle, G. Trueba, K. Levy. Antibiotic resistance in animal and environmental samples associated with smallscale poultry farming in northwestern Ecuador. mSphere 1(1):e00021-15. doi:10.1128/mSphere.00021- 15. (2016)

12. M.Z. El-Demerdash, M.F.A. Hanan, and E.A. Asmaa. Studies on mortalities in baby quail chicks. Proc. of the 6th Animal Wealth Research Conf. in the Middle East \& North Africa. 63-76 (2013)

13. N.T. Nhung, N. Chansiripornchai and J.J. Carrique-Mas. Antimicrobial Resistance in Bacterial Poultry Pathogens: A Review. Front. Vet. Sci. 4:126. doi: 10.3389/fvets.2017.00126 (2017)

14. C. Chauvin, L. Le Devendec, E. Jouy, M. Le Cornec, S. Francart, C. MaroisCréhan, I. Kempf. National prevalence of resistance to thirdgeneration cephalosporins in Escherichia coli isolates from layer flocks in France. Antimicrob Agents Chemother 57:6351- 6353. http://dx.doi.org/ 10.1128/AAC.01460-13 (2013)

15. D.A. Rowe-Magnus, A-M. Guerout, D. Mazel. Bacterial resistance evolution by recruitment of super-integron gene cassettes. Mol Microbiol 43:1657-1669 (2002)

16. J. Dugassa and N. Shukuri. Review on Antibiotic Resistance and Its Mechanism of Development. Journal of Health, Health, Medicine and Nursing 1:1-17 (2017) 
17. S. Galdiero, A. Falanga, M. Cantisani , R. Tarallo, M.E.D. Pepa, V. D’Oriano and M. Galdiero. Microbe-Host Interactions: Structure and Role of Gram-Negative Bacterial Porins. Current Protein and Peptide Science, 13 :843-854 (2012)

18. S.P. Denyer, N.A. Hodges, S.P. Gorman and B.F. Gilmore. Hugo and Russell. Pharmaceutical Microbiology. 8th Edition. Wiley Blackwell Publishing House, NewDelhi, India (2011)

19. J. Willey, L. Sherwood, C. Wolver ton. Prescott Microbiology. 9th Edition, McGrawHill, New Yk. (2013)

20. M. Gulmez, N. Gulmez, S. Bingol, T. Deprem and S.K. Tasci. The Effect of Dietary Inclusion of Probiotics on Growth and Intestinal Morphology of Broiler Chickens. J. World's Poult. Res. 9 (1): 24-31 (2019)

21. M. M. Rahman, A. Husna, H. A. Elshabrawy, J. Alam, N. Y. Runa, A. T. M. Badruzzaman, H. M. Ashour. Isolation and molecular characterization of multidrugresistant Escherichia coli from chicken meat. Scientific Reports, 10(1). doi:10.1038/s41598-020-78367-2 (2020)

22. A. Hussain, et al. Risk of transmission of antimicrobial resistant Escherichia coli from commercial broiler and free-range retail chicken in India. Front. Microbiol. 8 :2120 (2017)

23. R. Yulistiani et al. IOP Conf. Ser.: Mater. Sci. Eng. 633012007 (2019) 